pojednává o proniknutí prívlastků vyjádřených nesklonným prepozičním adjektivem do současného jazyka, uvádí různé způsoby klasifikace daných jazykových útvarů a porovnává jejich vznik a použití v současném ruském a českém jazyce.

Giuseppe Maiello se ve svém př́spěvku zabývá italskou koncepcí českého národního obrození a klade si otázku o možných př́ícinách „slabšího zájmu ze strany Itálie o tento důležitý moment českých dějin“ [POSPÍŠIL, ZELENKA, PAUČOVÁ 2018, 95].

Je patrné, že jednotlivé příspěvky sborníku jsou vzájemně propojené a zahrnují nejenom tradice, $\mathrm{z}$ nichž vychází česká slavistika, ale také poměrně nové jevy a tendence, které souvisí s novými technologiemi, obsahují též široké srovnávací studie stavu a dynamiky vývoje jazyka a literatury a jejich politické aspekty v prostoru slovanských kultur.

Tatjana Zaňko

\title{
Literatura:
}

POSPÍŠIL, I., ZELENKA, M., PAUČOVÁ, L. (2018) (eds): Česká slavistika 2018. Brno.

\section{Další svazek brněnské slavistiky ke střední Evropě}

POSPÍŠIL, I. (ed.): Střední Evropa včera a dnes: proměny koncepcí II. Brno: Středoevropské centrum slovanských studií, Jan Sojnek - Galium 2018. ISBN 978-80-88296-01-0.

Kolektivní publikace obsahuje materiály stejnojmenné mezinárodní vědecké konference, jež proběhla v půlce listopadu roku 2017 ve spolupráci Středoevropského centra slovanských studií a České asociace slavistů s Ústavem slavistiky FF MU a Slavistickou společností Franka Wollmana a je pokračováním tradice brněnských konferencí o střední Evropě. Rozsáhlý svazek plynule navazuje na jeho první část Střední Evropa včera a dnes: proměny koncepcí a je monografickou analýzou různých aspektů a konkrétním výzkumem jevů střední Evropy. Sborník je zdařilým pokusem o objasnění role a místa stř̌ední Evropy v dnešním evropském myšlení a také o vystižení hodnocení vývoje střední Evropy v posledních desetiletích. V úvodu editor monografie Ivo Pospíšil zmiňuje fenomén střední Evropy, která je spíše duchovním nežli geopolitickým prostorem, areálem. Publikace ve 36 př́spěvcích českých, polských, slovenských, madarských, ukrajinských, ruských a slovinských autorů svým způsobem 
sumarizuje a reviduje dosavadní stav komplexního seriózního a dlouhodobého bádání o středoevropské problematice.

Po obsahové stránce je sborník rozdělen do dvou oddílů: Jazyk - literatura kultura a Historie - filozofie - kulturní historie - politika - metodologie. První kapitola obsahuje 23 prŕspěvků, $\mathrm{v}$ jejichž centru je představena stř̌ední Evropa v zrcadle jazykovědných, literárněvědných a kulturologických souvislostí. Ondřej Bláha se zamýšlí nad historickými předpoklady konvergentního vývoje jazyků střední Evropy a tendenci $\mathrm{k}$ formalizaci věty vidí jako hlavní a nejdůležitější středoevropský jazykový rys. Jedním z nedostatečně prozkoumaných rysů středoevropského jazykového svazu, a to německými sémantickými kalky $\mathrm{v}$ češtině a jiných slovanských jazycích, se zabývá ve svém článku Marija Alexejevna Jelizarjeva. Otázky středoevropského jazykového svazu z hlediska jeho konstituování a konstituovanosti řeší Sergej Skorvid, jenž „se pokouší o konfrontaci výkladu různého počtu zjištovaných shod v pracích jednotlivých badatelů, včetně těch nejnovějších, a o rekonstrukci několika fází, které se vystřídaly v průběhu utváření daného jazykového areálu“ [POSPÍŠIL 2018, 177].

Tematické zaměření oblasti literárněvědných př́spěvků této kapitoly monografie je rozsáhlejší. Setkáváme se zde se zajímavými názory autorů, kteří se zabývají polskou literární vědou. Např́klad Andrzej Borkowski pojednává o cestovních zápiscích Jakuba Sobieského a o místě, které v nich zaujímá střední Evropa; Agnieszka Janiec Nyitrai žijící a pracující v Madarsku analyzuje sborník esejí Andrzeje Stasiuka Wschod (2014) v kontextu př́slušnosti Polska k Východu a Západu. Michał Kuran se zabývá projevy společenství myšlenek v literatuře střední Evropy na přelomu 16.-17. století.

Ukrajinská literatura je také nepochybně důležitým objektem bádání o střední Evropě, a to $\mathrm{v}$ článcích Ivana Fedečka, jenž věnuje svou pozornost významné osobnosti, ukrajinskému překladateli a publicistovi konce 19. - začátku 20. století Ivanu Frankovi, a Michajla Hnatjuka, který analyzuje východní tradice a středoevropské mezníky ukrajinské literatury 19. - začátku 20. století. Na pojetí slovenské literatury ve středoevropském kontextu se zaměřují Marta Germušková a Zuzana Chrenková, jejíž práce navazuje na metodologický model vymezený M. Bátorovou a zabývá se hloubkovou analýzou románu J. C. Hronského Pisár Gráč (1940); jeho typologické souvislosti odkazují k středoevropské literární a kulturní struktuře či kontextu. Tereza Šmídová sleduje míru ovlivnění a určování česko-slovenské fanfiction středoevropskými kulturními reáliemi.

Petr Kučera pohlíží na šumavskou literaturu jako na regionální literaturu středoevropské periferie a zaměřuje se i na její tendenčnost. Jana Waldnerová se zabývá poetikou humoru románové trilogie Poslední aristokratka současného českého spisovatele Evžena Bočka. S nacionalismem, světoobčanstvím a vnímáním vlastní historie a hlavně $\mathrm{s}$ „vnímáním odlišností a interpretacemi vlastních kořenů“ v tvorbě 
českého spisovatele a autora divadelních her a komiksů Jaroslava Rudiše nás seznamuje př́spěvek Martina Markoše, jenž sleduje „minulost postav, její vliv na současnost, souvislosti s významnými historickými událostmi, vlastní sebereflexe, vazby na jiné evropské země a hledání životních jistot" [POSPÍŠIL 2018, 155]. Na téma homosexuality na profesionální české divadelní scéně se zaměřuje př́spěvek Jaroslava Sommera, který zkoumá, jak často se objevují v českém divadle domácí a přeložené inscenace, do nichž „byl homosexuální motiv dosazen tvưrčím týmem, aniž by se vyskytoval v původní hře, literární či filmové předloze " [POSPÍŠIL 2018, 189-196]. O paralelách a hudebním principu, na nichž J. Škvorecký vybudoval svůj román Mirákl (Toronto 1972), pojednává František Všetička - srovnává Mirákl a Kunderův Život je jinde a ve způsobu tvorby obou autorů vidí ,jisté př́buzenství“ [POSPÍŠIL 2018, 229].

Ivo Pospíšil se zabývá analýzou tří dopisů Alfreda Bema, jenž poukazuje na úpadek sovětské literatury počátku 30. let 20. století a zároveň na její popularitu ve světě, a to z důvodu jejího „sepětí se současností, její aktuálnosti a líčení každodenního života“. Autor příspěvku přináší nové pohledy a kritické komentáře a „demonstruje, jak se jednotlivé národní literatury střídají ve světovém literárním kánonu v časových vlnách“ [POSPÍŠIL 2018, 163-175]. O hlavních tendencích v aktuální české recepci ruské literatury posledních 10 let na materiálu knižně vydaných překladů se dovídáme z prríspěvku Josefa Šaura, který uvádí, že většinou se překládají „díla kriticky zachycující ruské dějiny 2o. století a současné Rusko“, zdůrazňují se politické a společenské postoje autorů, pak ovšem „umělecká kritéria ustupují do pozadí" [POSPÍŠIL 2018, 197]. Eva Kudrjavceva Malenová studuje otázky četnosti překladů trilogie Neználka od Nikolaje Nosova v některých evropských zemích jakožto českého fenoménu ve středoevropském kontextu.

$\mathrm{K}$ příspěvkům komparativního rázu patří jednak článek Vladimíra Hegera, v němž autor srovnává prózy Austerlitz od W. G. Sebalda a Knihy fakubovy od O. Tokarczukové; tématem jejich děl je právě střední Evropa. Středoevropsky je zaměřen také prríspěvek Patrika Šenkára, který srovnává prozaickou tvorbu představitelů současné slovenské literatury v Rumunsku pro děti a mládež D. M. Anocové a J. Nováka.

Nelze rovněž opomenout příspěvek Jany Kostincové, který je věnován současné exofonní a multilingvální poezii a metodologicky vychází z poetiky překladu Marjorie Perloff a prezentuje několik př́kladů současné multilingvální literární tvorby. O osobnostech, jež doprovázejí národní a geopolitickou historii a prostř̌ednictvím krásné literatury, kulturní publicistiky nebo esejí jsou schopné vyjádřit svůj názor na politickou a národní situaci v zemi a v Evropě, pojednává Viera Žemberová ve svém článku s názvem Homo scribens versus homo politicus.

Tematické zaměření druhé kapitoly je velmi různorodé; jsou v ní prríspěvky zaměřené na historii a kulturu, filozofii a politiku, na metodologii. Iveta Bủžková zkoumá 
a porovnává eseje vybraných slovinských autorů, kteří se zabývali myšlenkou střední Evropy pod vlivem známé Kunderovy eseje. Odrazem česko-ukrajinských jazykových, ale také historických interferencí v současných vztazích mezi Čechy a Ukrajinci se ve svém článku zaobírá Tereza Žáková. Názory dvou významných ukrajinských emigrantů, slavistů a literárních vědců Dmytra Čyževského a Jurije Ševelova na střední Evropu jako geografický a kulturní areál ve svém příspěvku přehledně mapuje Oksana Blaškiv. Analýzou ruské populistické myšlenky o emigraci se zabývá Monika Grącka. S názory nizozemského sociálního antropologa Jacoba Vossesteina, jenž nám poskytuje neokoloniální obraz stř̌ední Evropy ve svém díle Working with Eastern Europe (2006), se setkáváme v článku Alexandry Gorodecké. Střední Evropu v kontextu postkoloniálních studií zkoumá a subjektivní zprávu o tom podává Michał Kopczyk. S nejvýznamnějšími geopolitickými a kulturními koncepty střední Evropy po roce 1918, které vycházely z panevropského hnutí vedeného Richardem Coudenhovem-Kalergim a středoevropského hnutí s vůdčí osobností Eleméra Hantose, nás seznamuje Miroslav Jeřábek. Ve svém příspěvku, jenž se týká fenoménu nových subjektů na slovinské politické scéně, hledá Alena Klvaňová odpověd' na otázku, zda tento fenomén narušil „stabilitu stranického systému Republiky Slovinsko“ [POSPÍŠIL 2018, 305]. Anna Kobylińska uvažuje nad př́íinami, podle nichž Slovensko chybí na performativní mapě polského literárního kritika Przemysłava Czaplińského, který v roce 2016 vydal svou knihu Poruszona mapa, jejíž některé pasáže jsou velmi provokativní. Markéta Poledníková se zabývá reflexí studií ruského filozofa V. S. Solovjova v českém a slovenském prostř̌edí v první polovině 2o. století, následně pak př̀d rokem 1989 a po něm. Reflexi středoevropské „solidarity otřesených“ v komparativním literárním aspektu přináší Karolina Pospiszil. Richard Změlík věnuje svůj př́spěvek problematice Digital Humanities, konkrétně interpretaci empirických modelů v literární vědě a hledá odpověd na otázku, jak je možné interpretovat statistické nebo kartografické modely v literární vědě. Krištof Jacek Kozak předkládá model střední Evropy jako kosmopolitního prostoru tolerantního spolužití národů s vlastní identitou, ve kterém je potlačen nadměrný nacionalismus.

Autoři svými př́spěvky nahlíží na střední Evropu z různých úhlů - od literární vědy, jazykovědy, kulturologie a areálových studií přes poetiku, komparatistiku až k historiografii, politologii, sociologii, pomocí nichž se vyzdvihují a studují aktuální problémy kulturního a geopolitického areálu středoevropských národů.

Tatjana Zaňko

\section{Literatura:}

POSPÍŠIL, I. (2018) (ed.): Střední Evropa včera a dnes: proměny koncepcí II. Brno. 